\title{
CRITICAL LEGAL STUDIES AND THE POLITICS OF SPACE
}

\author{
Chris Butler \\ Griffith University, Australia
}

\begin{abstract}
A growing body of work during the last two decades has become explicitly concerned with the interdisciplinary connections between law and questions of space. Traversing topics such as the regulation of the city, control of public space and the symbolic dimensions of spatial conflicts, this literature constitutes an important contribution to critical legal scholarship. However there is still much work to be done on the development of the theoretical foundations of this field. This article will present the writings of the French philosopher and sociologist Henri Lefebvre as revealing a sophisticated theory of space with potentially profound implications for the research program of critical legal studies. Lefebvrean ideas are directly relevant to the renewal of critical approaches to the structure and form of planning law and regimes of urban governance. His work also contains fertile resources for research into the transformation of traditional forms of political citizenship into the broader concept of urban citizenship. Both these examples highlight the importance of the politics of space for critical legal thought and the role Lefebvre's social theory may play in its future development.
\end{abstract}

\section{KEY WORDS}

critical legal geography; Henri Lefebvre; production of space; right to the city; space and politics

'...(T)here is a politics of space because space is political.' (Lefebvre 1978b: 345)

\section{INTRODUCTION}

In recent years, there has been a noticeable shift in the social sciences, to a concern with both the role of space in social explanation and the geographical dimensions of social life. One of the results of this shift can be observed in the development of critical approaches to human geography, which emphasise the spatial characteristics of a range of social relations and sites of social power (Benko and Strohmayer 1997; Gregory and Urry 1985; Keith and Pile 1993; Massey 1994). Another is the revival of urban sociology and a renewal of 
interest in 'the city' within the social sciences more generally (Amin and Thrift 2002; Gottdiener 1994a; Soja 2000; Watson and Gibson 1995). This shift is at least partly premised on an implicit acknowledgment of the convincing theoretical case which has been put by a number of writers, that spatial factors are crucial to an adequate understanding of social relations, particularly in light of the global transformations of social life during the decades following the second world war (Harvey 1989; J ameson 1991; Soja 1989).

An interest in spatial questions is also reflected in an emerging literature within socio-legal and critical legal studies, focused on the interdisciplinary connections between law and geography. There is now a significant body of literature concerned with the role of law in managing specific urban problems, whether at the level of the city (Blomley 2004; Frug 1980; 1993; 1998; Moran and McGhee 1998; Philippopoulos-Mihalopoulos 2007; Stanley 1996), the neighbourhood (Cooper 1996) or in relation to housing policy (Stewart and Burridge 1989); the geography of regulation (Goodwin and Painter 1996; Tickell and Peck 1995) and the control of public space (Mitchell 1997; Gulick 1998; Killian 1998). A number of recent edited collections and special issues of journals have demonstrated the breadth and scope of law and geography research (Blomley, Delaney and Ford 2001; Holder and Harrison 2003; Manderson 2005; Stanford Law Review 1996). Much of this literature is explicitly directed towards making connections between the concerns of critical legal studies and critical geography scholarship - a field that Nicholas Blomley and David Delaney have characterised as critical legal geography (Blomley and Bakan 1992; Blomley 1994; 2003a; Delaney 2004; 2003).

Despite the conscious appropriation of a wide range of social theory influences within this field, only a small number of writers have reflected in depth on the theoretical and methodological implications of the 'spatial turn' for critical legal studies. One key absence in this scholarship is an adequate recognition of the theoretical and sociological works of Henri Lefebvre, which have played a very influential role within the disciplines of geography, planning, cultural studies and sociology during the last three decades. Lefebvre was one of the most important intellectual figures of the twentieth century, although his 
stature and contributions to philosophy, sociology and urban studies have only relatively recently begun to be widely appreciated by scholars outside France. While a comprehensive analysis of Lefebvre's ideas has not yet been attempted within legal studies, in a recent issue of this journal, Edesio Fernandes has presented an accessible introduction to the concept of the 'right to the city' which Lefebvre introduced in the late 1960s (Lefebvre 1996). Fernandes identifies the influential role of this idea in both the contemporary urban politics of Latin America (including the passage of Brazil's City Statute in 2001), and in international moves to develop a 'World Charter on the Right to the City' (Fernandes 2007). Indeed, the right to the city is one of the more accessible concepts that Lefebvre's writing on the politics of urban space has generated, but it is one that emerged from a quite rich philosophical context. The primary aim of this article is to build on Fernandes' excellent exposition of this aspect of Lefebvre's work and provide legal scholars with a more comprehensive understanding of the key theoretical and methodological elements of his social theory.

The discussion will begin with a brief account of some of the writers who have grappled with the theoretical implications of the spatial turn for critical legal studies during the past two decades. While recognising the importance of these contributions, it will be argued that Lefebvre's writings on space, the city and urban politics may creatively inform the emerging research program of critical legal geography. The philosophical influences and tendencies of Lefebvre's social theory will be introduced, with an emphasis on his classic work The Production of Space. In that book, he articulates a theory of the produced nature of social space and the need to understand its physical, mental and lived dimensions. Without denying the broader implications of Lefebvre's work, it will be argued that it has obvious relevance for two specific areas of critical legal scholarship. The first is the renewal of critical approaches to the structure and form of urban governance and spatial planning regimes. The second is the potential of the right to the city to act as a fruitful basis for the displacement of formal notions of political citizenship by a broader concept of urban citizenship. Both these examples highlight the importance of the politics of space for critical 
legal thought, and the potential part that Lefebvre's social theory may play in its development. ${ }^{1}$

\section{CRITICAL LEGAL STUDIES AND THE 'SPATIAL TURN'}

One of the most prominent law and geography scholars during the past two decades has been Nicholas Blomley, whose first major work Law, Space and the Geographies of Power attempted to carve out a methodology for law and geography scholarship capable of avoiding two familiar traps. The first is the spatial fetishism of the early 'regionalist' school of comparative law which explained local legal orders in terms of the causal powers of geographic determinants such as climate, physical form and racial differences (Blomley 1994: 29-31; Economides, Blacksell and Watkins 1986: 163-4). The second trap is an unbalanced instrumentalism which takes for granted the objective status of an imperialist, positivist law imprinting itself on a passive space conceived as a flat surface or empty container (Blomley 1994: 29-36). Both these tendencies adopt a mono-directional notion of causality and implicitly separate law' and 'space' into distinct analytical realms.

In his early writing, Blomley attempts to bypass these pitfalls by arguing for a theory of law and geography which is rooted in the contingency of meaning and interpretation (Blomley 1989; 1994; Blomley and Bakan 1992; Blomley and Clark 1990; Clark 1989). This approach combines an awareness of the indeterminacy of legal discourse with critical geographic insights about the heterogeneity of social space. Accordingly law and space are both conceptualised as indeterminate but mutually constitutive (Manderson 1996: 1061). A direct consequence of this approach is that abstracted and reified understandings of law are undermined and replaced by a theory which recognises the contingency and context-specific nature of legal interpretation. More recently, Blomley has argued that dominant forms of spatio-legal relations can be explained as 'splices' or representational concepts which encode hegemonic meanings of law and space (Blomley 2003a: 29-32). He points to the case of the large number of disappearances and murders of women sex workers in Vancouver's Downtown Eastside, an area commonly identified by non-residents as rife with crime and social disadvantage. The victims' 
involvement in the sex trade and their spatial location worked in tandem to reinforce their positions as both legal and spatial outlaws, and legitimised the historical lack of public and official concern over these crimes for more than two decades. An Australian example of splicing can be drawn from the manufactured public and legal hostility shown towards asylum seekers in recent times, whose mode of entry to the country is characterised as illegal and simultaneously renders them outlaws in citizenship terms (Butler 2007; Duncanson 2003).

A number of other writers have also made symbolic use of space as a metaphor for indeterminacy, contingency and difference (Cooper 1998; Stanley 1996). Perhaps the most detailed and sophisticated attempt to theorise the relationship between law and space in this way, can be found in the work of Boaventura de Sousa Santos. Drawing on the methodology of legal pluralism, Santos describes the various spatial scales of law and regulatory phenomena (see also Blomley 1994: 42, 45-6; Clark 1989: 217; Pue 1990: 576). In numerous places he has used the metaphor of the map to chart the sites at which different modes of legal and social power operate (Santos 1995; 1987; 1985). He argues for a form of legal pluralism which moves from the understanding of different legal orders as separate entities coexisting in the same political space, to a

conception of different legal spaces superimposed, interpenetrated and mixed in our minds, as much as in our actions .... We live in a time of porous legality or legal porosity, multiple networks of legal orders forcing us to constant transitions and trespassings. Our legal life is constituted by an intersection of different legal orders, that is, by interlegality (Santos 1995: 473).

The concept of interlegality provides one means of understanding the ways in which legal spaces operate 'simultaneously on different scales' (Santos 1987: 288). It undermines the narrow, doctrinal closure of legal formalism and shows how 'state law' is at once connected to a range of alternative legalities and normative orders. This and the other attempts to flesh out the theoretical relationships between law and geography mentioned here have made 
significant contributions to this growing field. One of their limitations is the construction of the spatial turn in law as a particular instance of a more general 'interpretive turn' in the social sciences, which links it closely to the concerns of one tendency within cultural geography. ${ }^{2}$ David Delaney has recently argued for the importance of also acknowledging how '(spatiolegal) representations are imbricated with elements of the (spatiolegal) material world' (Delaney 2004: 851). In doing so, he has identified some of the key ways in which Lefebvrean ideas may contribute to a materialist theoretical framework for critical legal geography. The following sections of this article will build on the work of Delaney and Fernandes in demonstrating the relevance of Lefebvre's social theory in this regard.

\section{THEORY AND METHOD IN THE WORK OF HENRI LEFEBVRE}

In recent years Lefebvre's extensive contributions to philosophy, political theory, sociology, geography and state theory have been rediscovered in France, after two decades during which his work was academically marginalised by the dominance of structuralist and poststructuralist influences (Elden 2006). In the English-speaking world, there was little exposure or understanding of his work before the early 1990s, when the recent wave of translations of a number of his key texts began (Lefebvre 1991a; 1991b; 1995; 1996; 2002; 2003a; 2003b; 2004; 2005). ${ }^{3}$ His strongest influence in Anglophone countries has been on the discipline of critical human geography, where his ideas have been used as a source for the development of materialist approaches to space (Harvey 1973; Soja 1989; Gottdiener 1985/ 1994b). Largely because of this 'geographical' introduction of his work to the social sciences outside France, his writings on space and urban questions have tended to be much more widely read than other elements of his work. However, Lefebvre's vast intellectual output and the breadth of his subjects makes it difficult to adequately comprehend one aspect of his oeuvre without being aware of how it relates to others. While this article will primarily concentrate on Lefebvre's theory of space, it is worthwhile remembering that its insights are not usefully separated from his approach to philosophy, sociological method and political theory. 
Lefebvre's philosophical position can be most simply described as a humanist Marxism, supplemented by the ideas of Hegel and Nietzsche. ${ }^{4}$ Arguing that these three thinkers need to be read together, Lefebvre notes how Marx contributes the theoretical materials for a transformative critique of capitalist social relations, while Hegel reminds us of the overwhelming power of the state, and Nietzsche alerts us to the celebration of art, festival and bodily pleasures that are the hallmarks of civilised life (Lefebvre 2003a: 43-4). A number of philosophical themes recur in his writing, such as the pervasiveness of human alienation, the need to situate social phenomena within a totality which is constantly open to transformation and renewal (Lefebvre 1955), and his strident opposition to all forms of intellectual reductionism. In relation to the latter, Lefebvre particularly opposed the fragmentation of social thought into artificial specialisations and the collapsing of social relations into mental constructs, as can be observed in the various poststructuralist forms of philosophical idealism. This characteristic of Lefebvre's thinking makes it much more difficult to place his work under the umbrella of poststructuralism than has been asserted by some writers (Elden 2001; cf Dear 1997; Soja 1989).

Lefebvre's greatest sociological contribution lies in his work on 'everyday life' which establishes a framework for the study of daily existence within capitalist modernity. Begun in 1947, this project was not completed until the posthumous publication of Elements of Rhythmanalysis (Lefebvre 2004), often regarded as the unofficial fourth volume of his Critique of Everyday Life (Lefebvre 1991a; 2002; 2005). While it is not possible to detail the connections between Lefebvre's work on everyday life, space and social rhythms in this article, it is nevertheless important to acknowledge that Lefebvre's work on the everyday prefigures a number of his later concerns with spatial politics and the place of the body within social theory. For Lefebvre, the experience of everyday life is mediated and structured by the multifarious ways in which space is produced and because social space is the product of human agency, it in turn helps to shape social, economic, legal and political relations. Keeping these philosophical and sociological influences in mind, I will emphasise in the following sections how Lefebvre's account of the produced nature of space can 
provide theoretical resources for critical legal studies which avoid fetishising space or reducing it to a discursive or epistemic structure.

Lefebvre's writings on space, spatial relations and urbanism appear in numerous places throughout his vast written output. As early as 1939 in Dialectical Materialism (Lefebvre 1968), Lefebvre was beginning to pay attention to the spatial dimensions of the dialectic, in particular through recognising that production is both a spatial and temporal process (Gottdiener 1993: 135; Shields 1999: 119-20; Elden 2004b: 37). By the early 1970s Lefebvre had explicitly turned his attention to questions of space and the politics of urban life through his classic critique of post-war urban planning in France in 'Notes on the new town' (Lefebvre 1995) and in works such as The Right to the City (Lefebvre 1996: 61-181) and The Urban Revolution (Lefebvre 2003b). But the most comprehensive statement of his approach to space and its implications for social analysis is to be found in his 1974 book The Production of Space (1991b). The first thing to appreciate in reading this dense volume is the multiplicity of dimensions that space holds for him. Here space is not depicted merely as a geographical or physical location or a commodity, but as a political instrument, as part of the relations of production and property ownership, and as a means of creative and aesthetic expression. (Lefebvre 1991b: 349; Gottdiener 1985/ 1994b: 123)

At the core of Lefebvre's argument in The Production of Space is the claim that a particular 'common-sense' philosophy has structured the understanding of space and spatial relations in the social scientific disciplines since the Enlightenment. The intellectual roots of this philosophy lie in what Lefebvre describes as the absolute conception of space. This initially emerged from the Cartesian distinction between res cogitans (the thinking being) and res extensa (the physical world), in which space was conceived in geometric terms - as extension, rather than as an element of thought. Accordingly, it could be reduced to a set of coordinates, lines and planes, capable of quantitative measurement. This Cartesian account was supplemented and complicated by Kant's understanding of space and time as a priori categories which theoretically placed space within the realm of consciousness (Lefebvre 1991b: 
1-2; Elden 2004b: 186-7). These two primary influences have established a dominant philosophy of space which ontologically treats it as an empty vessel existing prior to the matter which fills it. Simultaneously, this ontology is combined with an epistemological reduction of space to an abstract, mental construction - a 'philosophy of space revised and corrected by mathematics' (Lefebvre 1991b: 3). Hence an empty and flattened ontology co-exists with a form of idealism which treats social relations as purely part of the epistemic realm.

The influence of this philosophy of space is clear in the natural sciences and particularly in disciplines such as mathematical modelling and in positivist geography where the abstraction and quantification of space has always been of supreme importance. However, Lefebvre argues that this philosophy of space and its implicit identification of mental space(s) with social and physical space has also embedded itself in a number of 'critical' approaches to social inquiry. These tendencies within social theory fetishise space as a purely epistemological category and collapse social relations into the realm of mental space. (Lefebvre 1991b: 3-6) Theorists such as Michel Foucault, Julia Kristeva, Jacques Derrida and Jacques Lacan are criticised by Lefebvre for oscillating between attempts to impose a systematic logic on social analysis and accepting 'a chasm between the logical, mathematical, and epistemological realms ... and practice'. (Lefebvre 1991b: 300)

These passages of The Production of Space explicitly critique both positivist models of science and the idealist currents of French poststructuralism. But a deeper and more substantial argument of the book is that our understanding of space must move beyond the unhelpful dichotomy between the physical dimensions of space and abstract conceptions of it. By reinforcing the fragmentation of the mental, physical and social fields, the vast bulk of the social sciences have relied upon an impoverished understanding of space. Law is no exception in this regard, through its imposition of abstract categories such as the public/private distinction, property rights and contractual relations on social life. In doing so, it instrumentalises and commodifies space, effacing the full diversity of spatial uses. 


\section{THE PRODUCTION OF SPACE}

Lefebvre's overriding concern in The Production of Space is to reduce this artificial fragmentation of social thought and to link the mental, physical and lived dimensions of space in ways which emphasise how space is produced through human agency (Lefebve 1991b: 11). Drawing on Leibniz's relative or relational conception of space (Leibniz 1956/ 1969: 675-721), Lefebvre explains these three aspects of space as internally related within an open totality. He establishes a conceptual triad which expresses the complex interaction and dialectical unity of spatial relations, consisting of the following elements:

a) Spatial practices which are the physical practices, everyday routines, networks and pathways through which the totality of social life is reproduced. These practices include both individually embodied social rhythms and collective patterns of movement within cities and regions. Writing in the early 1970s, Lefebvre describes a paradigmatic example of 'modern' spatial practice in terms of:

... the daily life of a tenant in a government-subsidised high-rise housing project. Which should not be taken to mean that motorways or the politics of air transport can be left out of the picture. (Lefebvre 1991b, $38)^{5}$

b) Representations of space are forms of abstract knowledge generated by formal and institutional apparatuses of power engaged in the organisation of space. Obvious examples include the work of planners, bureaucrats, social engineers, cartographers and the variety of scientific disciplines holding socially recognised 'expertise' in the management and control of spatial form (Lefebvre 1991b: 38-9).

c) Representational spaces are closely associated with the social and bodily functions of lived experience, these form part of the social imaginary of 'inhabitants and users' of space through which complex symbols are linked to non-hegemonic forms of creative practice and social resistance (Lefebvre 1991b: 33, 38). ${ }^{6}$ 
The delineation of these three dialectically related dimensions of space - the physical, the mental and the lived - is central to Lefebvre's explanation of the production and social use of space. He posits it as a counter-move against dominant tendencies that treat social space as a mere object or a receptacle, and then subsume the social and physical aspects of space into abstract mental formulations. Each of the components of this conceptual triad operate simultaneously, and provide the groundwork for Lefebvre's description of the multi-dimensionality of social space. As we would expect from his rejection of the absolute conception of space, Lefebvre is not content to see space as a mere object or a receptacle. Instead he describes it as a social matrix that operates as a 'presupposition, medium and product of the social relations of capitalism' (Brenner 1997: 140). Social space is simultaneously:

a) A part of the forces of production which progressively displaces and supplants the role of (first) nature.

b) A product that is consumed as a commodity and as a productive resource in the social reproduction of labour power.

c) A political instrument that facilitates forms of social control.

d) The basis for the reproduction of property relations through legal and planning regimes which order space hierarchically.

e) A set of ideological and symbolic superstructures.

f) A means of human reappropriation through the development of counter-spaces forged through artistic expression and social resistance. (Lefebvre 1991b: 349)

This definition allows Lefebvre to understand space as an ensemble of relations and networks that make social action possible. The first two elements recognise how space forms part of processes of production and social reproduction, the next two identify it as a mechanism of state regulation and the site of political struggle and human creativity. The final two points make clear that social conflicts have spatial dimensions in addition to traditionally acknowledged political and economic ones. The multiplicity of roles that space performs in production and social reproduction is perhaps the most crucial implication that Lefebvre derives from Leibniz's assertion of the 
necessity for 'space to be occupied' by the body (Lefebvre 1991b: 169-71). While the absolute conception of space encourages a separation of formal space and material content, Lefebvre's relational depiction of space presupposes an immediate relationship between the whole body and its space. In theorising this occupation of space, Lefebvre is led to understand production as the means through which the living body as a deployment of energies, produces space and reproduces itself within the limits and laws of that space.

Particularly influenced by his reading of the early Marx, Lefebvre re-crafts and expands Marx's model of commodity production to explain how space is produced and contributes to the reproduction of the social relations of capitalism. Production extends beyond the manufacture of commodities and the confines of the labour process and also encompasses artistic creations and the built environment alongside the social relations of production. This provides him with the tools to understand space in a way that is unique in social theory. Not only does he identify space as an outcome of the productive process, it is also part of the means of production as a 'network of exchanges and flow(s) of raw materials and energy', (Lefebvre 1979: 287) and as one of the forces of production alongside labour and technology.

Lefebvre's definition of space extends beyond the various ways in which it is inscribed within processes of production and reproduction. The multidimensionality of space includes its political status as a means of social regulation and as the site of political struggle. The provision of relatively stable forms of territorial organisation for the circulation and accumulation of capital necessarily requires state planning, regulation and the administration of urban space. This facilitates the fulfilment of capital's drive for (in Marx's words) the 'annihilation of space by time'. (Marx 1973: 539) Extended capital accumulation can only be secured through the 'spatial fix' (Harvey 1982: 41444) offered by state construction of 'fixed and immobile transport, communications and regulatory-institutional infra-structures' (Brenner 1999: 433). These intensive and extensive interventions of the state in economic and social life must be 'conceived spatially as attempts to organise, 
instrumentalise and regulate social space' (Brenner 1997: 146). They provide the means for the political production of a social world organised to eliminate the spatial constraints to accumulation.

As identified previously, the final two points in Lefebvre's definition of social space are a recognition that the political dimensions of space extend beyond its management and use as a political tool by the state. Space is itself a site of political conflict in which the class struggle has increasingly been transformed into forms of conflict which are spatial as well as political and economic. Class relations cannot be understood as mechanically 'projected onto space', rather social conflicts are driven by the dynamic of a spatial dialectic that cuts across traditional class distinctions. Accordingly, counter-hegemonic struggles must confront existing forms of organisation and control of space through alternative uses of space - effectively the production of counter-spaces. Lefebvre specifically cites the example of the informal, popular types of spatial restructuring by excluded urban communities in Latin America (favelas). These communities have developed forms of social ordering, architecture and planning which demonstrate the possibility of reappropriating space and decentring institutionalised forms of spatial organization (Lefebvre 1991b: 373-4). ${ }^{7}$ Understanding the political nature of space can assist in this reappropriation of space - reasserting use values and creativity over exchange and domination, and restoring lived time outside the sphere of work. In Lefebvre's words: '(s)pace remains a model, a perpetual prototype of use value resisting the generalizations of exchange and exchange value in a capitalist economy under the authority of a homogenizing state' (Lefebvre 1979: 291).

In this complex and layered account, space is understood as neither simply a physical container of objects, nor an infinite, discursive field. It is both socially produced and an essential precondition for the reproduction of social relations. Space forms part of the state's productive machinery of social regulation, while also operating as a site of political struggle and creative appropriation. Such insights may be of immense benefit to the development of critical legal geography and assist in building on the theoretical work of writers such as Blomley and Santos. However it is important that scholars 
working in this field remain attuned to the dialectical relationship between the instrumental use of space and the political possibilities inherent in its material and symbolic production. Law needs to be understood as a set of techniques of spatial organisation and governance - a body of spatial representations and as a framework for an ensemble of everyday spatial practices.

One welcome move in this direction is provided by David Delaney's introduction of the concept of the 'nomosphere' to refer to 'the cultural material environs' that are constituted by the simultaneous materiality of legal relations and law's discursive representation of socio-spatial relations. (Delaney 2004: 852) Drawing on Lefebvre's spatial triad, Delaney recognises how it provides a way for critical legal analysis to balance the mental and physical dimensions of the social world with the realm of the lived. Both spatial practices and the representations of space which tend to be imposed by law are intersected by representational spaces, embodying spatialised resistances to legal ordering. Law is simultaneously a body of ideological representations of space and a collection of material practices which maintain social order and govern social space. Such an account of law's role in the production of space avoids the traps of geographical determinism and legal instrumentalism identified by Blomley, but it also eschews theoretical tendencies to reduce space to a linguistic model and conceive of it as a metaphorical source of indeterminacy and social contingency. These tendencies inevitably prioritise mental conceptualisations of space, over its material and lived dimensions. ${ }^{8}$

\section{LAW, STATE POWER AND THE EMERGENCE OF}

\section{ABSTRACT SPACE}

Central to Lefebvre's theory of social space is his reworking of Marx's chronology of historical stages of social development as a history of modes of production of space. While Marx's method worked backwards from the fruits of production to productive activity itself, Lefebvre extends this by arguing that 'any activity developed over (historical) time engenders (produces) a space, and can only attain practical 'reality' or concrete existence within that space'. (Lefebvre 1991b: 115) A spatial history of this sort is therefore, 
implicitly an explanation of the spatial prerequisites for the genesis of modern capitalism. Just as the emergence of the first city-states or the rise of mercantilism in Europe during the Middle Ages brought with them transformations in the relationship between town and country (Lefebvre 1991b: 234-41, 256-263, 271), so too contemporary capitalism has produced a new spatial form. Lefebvre labels this abstract space - the fragmentary, pulverised space created by the imperatives of capital and the state's management and domination of space (Lefebvre 1991b: 285-9). It not only nurtures and facilitates the reproduction of capitalist social relations, it actively excludes alternative spatial uses.

Lefebvre outlines three tendencies which simultaneously characterise abstract space. These are orientations towards fragmentation, homogeneity, and hierarchy (Lefebvre 2003a: 210; Martins 1982: 177-8; Gottdiener 1985/ 1994b: 126). Fragmentation is perhaps the most obvious characteristic of the spatial organisation of the contemporary world. It is manifested in the breaking down of space into discrete units which can be privatised and traded as commodities and is enhanced by the fragmentation of the sciences into separate domains which carve up space according to disciplinary interests. Each area of knowledge adopts its own segmented portion of the objects in space which are ripe for analysis. Just as the fetishism of commodities arises from treating 'things in isolation', so too the intellectual fragmentation of space introduces a fetishism of space (Lefebvre 1991b: 89-90). Co-existing with the fragmentation of abstract space is a seemingly contradictory tendency towards homogenisation. Taken at face value, modern life displays an extraordinary diversity of consumable products and styles: a diversity of things in space. However, as Lefebvre makes clear, '(a)bstract space is not homogeneous; it simply has homogeneity as its goal, its orientation, its lens" (Lefebvre 1991b: 287). Abstraction may break up space into fragments, but it also imposes a logic of exhangeability on places and times (Martins 1982: 177). The application of the criteria of pure exchange to space operates as an homogenising force which has the power to flatten-out spatial diversity on a global scale. 
The coalescence of forcibly homogenised and fragmented spaces reveals the third tendency of abstract space - towards its hierarchical ordering at the behest of economic, technological, administrative and political power. The position of a particular space within the hierarchy is determined by its position in the conflictive relationship between centres and peripheries which manifests itself in the distribution of power, wealth, resources and information (Martins 1982: 178). This hierarchy between centre and periphery is not the random result of an evolutionary process. Rather, it is the product of a strategic logic in which the centre organises that which is 'around it, arranging and hierarchising the peripheries' (Lefebvre 1976: 17). It is here that we can begin to observe the importance of state power in the construction of abstract space. The state actively intervenes in the production of space, treating it as a political instrument through which social order can be maintained. Through its roles as the provider of infrastructure and the manager of resources, alongside its subsidisation policies and spatial planning regimes, the state is largely responsible for the template on which abstract space is built (Lefebvre 1978a: 307-8). The production of space and the ordering of its dominant uses require the prohibitions and sanctions imposed by the state through the legal order. Lefebvre argues the juridical form of private property relations is inherently based on spatial prohibitions which prescribe the limits of everyday life and serve as the reverse side of the negative appropriation of space under the reign of private property' (Lefebvre 1991b: 319). Abstract space is characterised by both a normative and discursive non-aggression pact and the coercive exercise of institutional power to preserve an apparently 'non-violent' social order (Lefebvre 1991b, 56-7). It therefore achieves a repressive efficiency which hides deceptively behind the pretence of civic peace and consensus.

These insights into the state's role in the production of abstract space are immediately relevant to the renewal of critical inquiries into the structure and form of contemporary spatial projects such as urban governance and planning law. Regimes of urban governance can be conceptualised as intrinsic parts of the contemporary state's ensemble of socio-spatial rules, techniques and ideological representations. Neil Brenner has recently incorporated Lefebvre's 
analysis in explaining how urban governance has operated as a crucial institutional support for the restructuring and spatial rescaling of the state in the era since the 1970s (Brenner 2004a; 2004b; 1999; 1997). However, it is important to note in this context, that Lefebvre has his critics. Mariana Valverde has pointedly questioned whether Lefebvre's 'abstractions about space in general' can contribute very much to understanding the concrete ways in which regulatory powers are deployed 'in everyday legal governance' (Valverde 2005: 55). Rather than embracing functionalist, class-based explanations of urban legal mechanisms relied upon in Marxist, 'structural' accounts of the politics of space, Valverde argues that a more fertile mode of inquiry involves close empirical investigations of the operation of commonplace techniques of municipal governance (Valverde 2005: 35, 46-7, $55)$.

Perhaps ironically, this criticism is not the first time the 'abstract' qualities of Lefebvre's writing have been noted. Indeed the complex and circuitous manner in which The Production of Space is structured has led some commentators to question its value as a piece of social theory (Molotch, 1993: 893; Sayer 1993; Unwin, 2000: 19-20). While it is true that the density of Lefebvre's style can at times obscure his message, it is not the case that his theory of space can be easily subsumed within the protocols of orthodox Marxist urban analysis. On the contrary, the attraction of his work is largely due to its anti-essentialist and non-reductionist orientation, which reveals the inherent complexity of space (Merrifield, 1995: 299). Consequently, scholarship on urban governance which is informed by Lefebvre's theoretical approach is capable of simultaneously conceptualising law as a tool of the state in its strategies of spatial production, and as a politically contested body of spatial representations. Elsewhere I have deployed Lefebvre's thinking in analysing the orthodox tools of land-use planning by demonstrating that zoning is both a codification of dominant representations of space, and a technical mechanism for reproducing that dominance, by inscribing them in physical uses of land (Butler, 2005: 21-2). Dividing space into zones, imposing homogeneity within them and hierarchically organising these fragments of space has proved a crucial vehicle for the reproduction of abstract space. The 
more recent emergence in Australia of neoliberal regimes of urban governance has heightened these tendencies towards abstract space, by introducing market mechanisms into the development approval process (Butler, 2004). ${ }^{9}$

\section{THE POLITICS OF SPACE: CITIZENSHIP AND THE RIGHT TO THE CITY}

Lefebvre's depiction of abstract space gives rise to another potentially fruitful area for critical legal investigation. The dominance of abstract space in Lefebvre's account is never total or absolute and its social relations must be continually reproduced and reimposed. He likens this process to a trial by space - 'an ordeal which is the modern world's answer to the judgement of God or the classical conception of fate' (Lefebvre 1991b: 416; Guidry 2003). Whatever is put into the dock, whether philosophy, religion, science or law, is subjected to an aggressive cross-examination which places a perpetual, contrary pressure on established forms of spatial power. This necessarily leaves open the possibility of future transformations through the generation of new socio-spatial orders. Inevitably, all political and social movements attempting to assert contrary impulses to those of the dominant spatial order must also undergo the judgment of a trial by space. As Neil Brenner describes it, '(t)he viability of all transformative political strategies depends crucially upon their ability to produce, appropriate and organise social space' (Brenner 1997: 152). For Lefebvre, 'groups, classes or fractions of classes cannot constitute themselves, or recognise one another as 'subjects' unless they generate (or produce) a space.' (Lefebvre 1991b: 416-7)

This account of the politics of abstract space directly points us to some of the political and legal implications of Lefebvre's theoretical enterprise. Given that space is a vehicle for the reassertion of use values and creativity over exchange and domination, counter-hegemonic and emancipatory political tendencies must aim towards the self-management of space. Accordingly, relationships between the state and its citizens are framed by struggles for what is defined by Lefebvre as the 'right to the city' - or the right to urban life. For Lefebvre, the urban is not simply a product of processes of industrial production and capital accumulation. It is 'more or less the oeuvre of its citizens' (Lefebvre 1996: 117) - a work of art constantly being remade. The prevention of certain 
groups and individuals from fully participating in this collective, creative act constitutes a denial of the right to the city.

Lefebvre argues that the right to the city is neither a natural nor a contractual right (Lefebvre 1996: 194) but is grounded in the entitlement to physically occupy urban space. It emerges from the essential qualities of the urban - as a space of centrality, gathering and convergence (Lefebvre 1996: 131, 195). It 'gathers the interests ... of the whole society and firstly of all those who inhabit' (Lefebvre 1996: 158). Here Lefebvre is drawing attention to more than material questions about the adequacy of collective urban services. He emphasises the importance of the full use or appropriation of space by those who inhabit the city. It is a right not to be expelled from social life and a rejection of enforced segregation to the urban peripheries, with the daily schedule this imposes. The right to the city is also a recognition of the importance of the urban as a space of encounter, allowing differences to flourish in order to facilitate the possibility of collective political action. ${ }^{10}$ Lastly, it is a demand for a participatory role in 'all circuits of decision-making leading to the control and development of the organisation of social space' as a means of resisting the control of space by the state, its planning bureaucracies, and capital (Martins 1982: 183).

Recently, a number of writers have proposed the right to the city as a potential basis for the replacement of formal notions of political citizenship with the broader concept of 'urban citizenship' (Fernandes 2007; 2006; Purcell 2003; Purcell 2002; Butler 2007; McCann 1999; McCann 2002; Isin 2000). Mark Purcell describes how this right can transform the power relations that underlie the production of space, fundamentally shifting control away from capital and the state and toward urban inhabitants' (Purcell 2002: 101-2). A right to inhabit space would concretise the rights of the citizen as a user of multiple urban services (Kofman and Lebas 1996: 34), and directly challenge the dominance of more limited liberal-democratic/Westphalian' forms of political citizenship. Indeed, by defending 'urban liberties' and protecting inhabitants against forms of spatial exclusion (Lefebvre 1996: 141; Lefebvre 2003a: 238-54), this new form of spatial citizenship may prove more 
democratic than traditional conceptions of citizenship - linked as they are to the historically sovereign nation-state, which is globally under challenge from processes of scalar restructuring and reterritorialisation (Purcell 2003: 565; Brenner 2004a; 1999). Recently I have written of how the right to the city as an entitlement that flows from the inhabitance of urban space, may be used to defend the interests of asylum seekers living in Australia under various temporary forms of refugee protection (Butler 2007).

In his recent discussion of this issue, Fernandes rightly identifies an urgent need for critical scholars to engage with the legal dimensions of the right to the city, and its implications for both urban law reform and new models of spatial citizenship (Fernandes 2007: 208). He draws on both the history of law reform movements in Latin America, and more particular instances such as Brazil's Federal 'City Statute' in 2001 and the current UN HABITAT/ UNESCO negotiations on a 'World Charter on the Right to the City' to argue that the concrete development of this right will depend on the social mobilisation of urban inhabitants. Taking a cue from Lefebvre's original formulation, he reminds us that any meaningful 'right to habitation' must be pursued alongside the 'right to participation' in social life. The extent to which the recognition of such rights has been the subject of intense political and legal contestation in Brazilian cities provides a salutary lesson for critical scholars on the inevitable obstacles to be overcome in the extension of the right to the city to other legal contexts (Fernandes 2007: 218).

\section{CONCLUSION}

Lefebvre offers a distinctive and sophisticated theory of space which draws attention to its physical, symbolic and lived dimensions. A key task in his writing is to link our analysis of social phenomena to both the socially produced character of space and its role in social reproduction. The brief account of his thought presented here has highlighted a number of important theoretical orientations and methodological themes in Lefebvre's work, and has identified some of the ways in which they may helpfully contribute to critical legal studies. Theoretically, his work avoids an excessive methodological reliance on metaphorical associations between 'mental spaces' 
and interpretive indeterminacy. It allows us to chart a course between the pitfalls of spatial fetishism and instrumentalist understandings of law's role in the production of space. In more applied areas of critical legal research, Lefebvre's ideas have begun to inform scholarship on the regulation of public space (Mitchell 1997, 2003; Gulick 1998; Killian 1998) and on critiques of the law of property (Blomley 1997a; 1997b; 1998; 2003b; Delaney 2001). This article has explored how Lefebvre's explanation of the state's role as a producer of space may valuably contribute to the renewal of critical approaches to regimes of spatial planning and urban governance. Avoiding cruder forms of instrumentalism that have characterised elements of orthodox Marxist urban studies, Lefebvre provides a way of conceptualising the tools of municipal governance simultaneously as codifications of dominant representations of space, and as technical mechanisms for inscribing dominant uses in space.

Finally, the discussion here has highlighted how Lefebvre's concept of the right to the city emerges directly from his philosophical and sociological writings on space. The requirement for abstract space to be perpetually reproduced opens up the possibility for contrary tendencies to challenge dominant forms of spatial ordering. It is in this inevitably political context that Lefebvre articulates the right to the city, constantly reasserting itself against the control of space by the state and capital, as one means of pursuing an emancipatory spatial practice. This right has already proved a fertile resource, both for activists in the contemporary urban politics of Latin America, and in recent research on the spatialisation of traditional conceptions of political citizenship. These and other topics at the intersection of the disciplines of law and geography will continue to generate new areas of inquiry for critical legal scholarship. It is hoped that the next wave of critical legal geography will be enriched by Henri Lefebvre's social theory, which remains a pioneering contribution to our understanding of the politics of space. 


\section{NOTES}

An earlier version of this article was completed with the assistance of a grant provided by the Socio-Legal Research Centre at Griffith University.

${ }^{1}$ Other areas where clear connections exist between Lefebvre's social theory and the concerns of critical legal studies include research on the regulation of public space (Killian 1998; Mitchell 1997; 2003), property relations (Blomley 1997a; 1997b; 1998; 2003b; Delaney 2001) and the interaction between law and everyday life (Sarat and Kearns 1993; Ewick and Silbey 1998).

2 This is explicitly acknowledged in the work of Blomley and Gordon Clark (Blomley and Clark 1990: 438; Clark 1989). For a robust critique of this aspect of their approach, from a Marxist-feminist perspective see Chouinard 1994: 424-7. Despite these reservations, Blomley's work in recent years has provided excellent examples of the radical possibilities of law and geography research (Blomley 1997a; 1997b; 1998; 2003b; 2004).

${ }^{3}$ For an earlier and generous portrayal of the significance of Lefebvre's influence on the western, humanist Marxist tradition see Anderson (1976). Other acknowledgements of his place within the French intellectual left appear in Burkhard 2000; Elden 2004b; Kelly 1982 and Poster 1975.

${ }^{4}$ Stuart Elden has argued that the influence of Heidegger on Lefebvre's thought has been unduly neglected (Elden 2004a; 2004b: 76-83).

${ }^{5}$ While this example is obviously rooted in the context of French urban planning in earlier decades, it clearly depicts the relationship in Lefebvre's thought between spatial practice and the concept of everyday life.

${ }^{6}$ It should be noted that representational spaces is the translation of les espaces de representation given by Donald Nicholson-Smith in Lefebvre 1991b. A number of other writers prefer the phrase 'spaces of representation'. (See Elden 2004b; Shields 1999; Stewart 1995).

${ }^{7}$ However as Fernandes and other writers have recognised, ending the exclusion of these communities from full social participation requires the recognition and accommodation of these settlements within the dominant legal order (Fernandes 2007; 1993; Guidry 2003; Santos 1977; 1992).

${ }^{8}$ Delaney's use of Lefebvre's materialist theory of space in this regard provides a indication of its broader capacity to contribute to the recent renewal of Marxist influences in critical legal theory (see Miéville 2005; Negri 2005; Douzinas 2000).

${ }^{9}$ At a deeper level, there is certainly another legitimate question that can be raised about Lefebvre's critique of abstract space. David Cunningham has identified the 
opposition that Lefebvre posits between 'abstraction' and 'difference' and notes the philosophical impossibility of escaping from certain forms of abstraction in the production of alternative spaces (Cunningham 2005: 22-3).

${ }^{10}$ Indeed in The Production of Space, Lefebvre identifies a logical companion to the right to the city as the 'right to difference'. This arises out of material and practical fights to assert social differences which exceed both the differentiations induced by the fragmentation of abstract space and those based on 'natural' or biological characteristics (Lefebvre 1991b: 64; Lefebvre 1971).

\section{REFERENCES}

Amin, Ash and Nigel Thrift (2002) Cities: Reimagining the Urban. Cambridge: Polity Press.

Anderson, Perry (1976) Considerations on Western Marxism. London: New Left Books.

Benko, Georges and Ulf Strohmayer (eds) (1997) Space and Social Theory: Interpreting Modernity and Postmodernity, Oxford: Blackwell.

Blomley, Nicholas (1989) 'Text and Context: Rethinking the Law-Space Nexus', Progress in Human Geography, 13(4): 512-34.

Blomley, Nicholas (1994) Law, Space and the Geographies of Power, London: Guilford Press.

Blomley, Nicholas (1997a) 'Property, Pluralism and the Gentrification Frontier', Canadian J ournal of Law and Society, 12(2): 187-218.

Blomley, Nicholas (1997b) The Properties of Space: History, Geography, and Gentrification', Urban Geography, 18(4): 286-295.

Blomley, Nicholas (1998) 'Landscapes of Property', Law and Society Review, 32(3): 567-612.

Blomley, Nicholas (2003a) 'From 'What?' to 'So What?': Law and Geography in Retrospect', pp. 17-34 in J. Holder and C. Harrison (eds) Law and Geography. Oxford: Oxford University Press.

Blomley, Nicholas (2003b) Law, Property, and the Geography of Violence: the Frontier, the Survey and the Grid', Annals of the Association of American Geographers, 93(1): 121-41.

Blomley, Nicholas (2004) Unsettling the City: Urban Land and the Politics of Property. NewYork: Routledge.

Blomley, Nicholas and J oel Bakan (1992) 'Spacing Out: Towards a Critical Geography of Law', Osgoode Hall Law J ournal, 30(3): 661-90. 
Blomley, Nicholas and Gordon Clark (1990) 'Law, Theory and Geography', Urban Geography, 11(5): 433-46.

Blomley, Nicholas, David Delaney and Richard Ford (eds) (2001) The Legal Geographies Reader: Law, Power, and Space. Malden, Mass: Blackwell.

Brenner, Neil (1997) 'Global, Fragmented, Hierarchical: Henri Lefebvre's Geographies of Globalization', Public Culture, 10(1): 135-67.

Brenner, Neil (1999) 'Globalisation as Reterritorialisation: The Re-scaling of Urban Governance in the European Union', Urban Studies, 36(3): 431-51.

Brenner, Neil (2004a) New State Spaces: Urban Governance and the Rescaling of Statehood. Oxford: Oxford University Press.

Brenner, Neil (2004b) Urban Governance and the Production of New State Spaces in Western Europe, 1960-2000', Review of International Political Economy, 11(3): 447-488.

Burkhard, Bud (2000) French Marxism Between the Wars: Henri Lefebvre and the Philosophies. New York: Humanity Books.

Butler, Chris (2004) Law and the Social Production of Space. Unpublished PhD thesis, Brisbane: Griffith University.

Butler, Chris (2005) 'Reading the Production of Suburbia in Post-War Australia', Law Text Culture, 9: 11-33.

Butler, Chris (2007) 'Sydney: Aspiration, Asylum and the Denial of the Right to the City', pp205-20 in A. Philippopoulos-Mihalopoulos (ed) Law and the City. Abingdon: Routledge-Cavendish.

Cheah, Pheng, David Fraser and J udith Grbich (1996) Thinking Through the Body of the Law, St. Leonards: Allen \&Unwin.

Chouinard, Vera (1994) 'Geography, Law and Legal Struggles: Which Ways Ahead?', Progress in Human Geography, 18(4): 415-40.

Clark, Gordon (1989) 'Law and the Interpretive Turn in the Social Sciences', Urban Geography 10(3): 209-228.

Cooper, Davina (1996) 'Talmudic Territory? Space, Law, and Modernist Discourse', J ournal of Law and Society, 23(4): 529-48.

Cooper, Davina (1998) Governing Out of Order: Space, Law and the Politics of Belonging. London: Rivers Oram Press.

Cunningham, David (2005) The Concept of Metropolis: Philosophy and Urban Form', Radical Philosophy, 133: 13-25.

Dear, Michael (1997) 'Postmodern Bloodlines', pp. 49-71 in G. Benko and U. Stromayer (eds) Space and Social Theory: Interpreting Modernity and Postmodernity, Oxford: Blackwell. 
Delaney, David (2001) 'Running With the Land: Legal-Historical Imagination and the Spaces of Modernity', J ournal of Historical Geography, 27(4): 493-506.

Delaney, David (2003) Beyond the Word: Law as a Thing of This World', pp. 67-83 in J. Holder and C. Harrison (eds) Law and Geography, Oxford: Oxford University Press.

Delaney, David (2004) Tracing Displacements: or Evictions in the Nomosphere', Environment and Planning D: Society and Space, 22: 847-60.

Douzinas, Costas (2000) 'Human Rights and Postmodern Utopia', Law and Critique, 11(2): 219-40.

Duncanson, Ian (2003) 'Telling the Refugee Story: the 'Ordinary Australian', the State of Australia', Law and Critique, 14: 29-43.

Elden, Stuart (2001) Politics, Philosophy, Geography: Henri Lefebvre in Recent Anglo-American Scholarship', Antipode, 33: 809-25.

Elden, Stuart (2004a) 'Between Marx and Heidegger: Politics, Philosophy and Lefebvre's The Production of Space', Antipode, 36: 86-105.

Elden, Stuart (2004b) Understanding Henri Lefebvre: Theory and the Possible, London: Continuum.

Elden, Stuart (2006) 'Some Are Born Posthumously: the French Afterlife of Henri Lefebvre', Historical Materialism, 14(4): 185-202.

Economides, Kim, Mark Blacksell and Charles Watkins (1986) 'The Spatial Analysis of Legal Systems: Towards a Geography of Law?' J ournal of Law and Society, 13(2): 161-81.

Ewick, Patricia and Susan Silbey (1998) The Common Place of Law: Stories From Everyday Life. Chicago: University of Chicago Press,

Fernandes, Edesio (1993) The Legal Regularization of "Favelas" in Brazil: The Case of Belo Horizonte', Social and Legal Studies, 2: 211-36

Fernandes, Edesio (2006) 'Updating the Declaration of the Rights of Citizens in Latin America: Constructing the "Right to the City" in Brazil", pp. 40-52 in Urban Policies and the Right to the city. Paris: UNESCO.

Fernandes E (2007) 'Constructing the 'Right to the City' in Brazil', Social and Legal Studies, 16(2): 210-19.

Frug, Gerald (1980) 'The City as a Legal Concept', Harvard Law Review, 93: 10571154.

Frug, Gerald (1993) 'Decentering Decentralization', University of Chicago Law Review, 60: 253-338.

Frug, Gerald (1998) 'City Services', New York University Law Review, 73: 23-96. 
Goodwin, Mark and J oe Painter (1996) 'Local Governance, the Crises of Fordism and the Changing Geographies of Regulation', Transactions of the Institute of British Geographers, 21(4): 635-648.

Gottdiener, Mark (1993) 'A Marx for Our Time: Henri Lefebvre and The Production of Space', Sociological Theory, 11(1): 129-36.

Gottdiener, Mark (1994a) The New Urban Sociology. New York: McGraw-Hill.

Gottdiener, Mark (1985/1994b) The Social Production of Urban Space, 2nd ed. Austin: University of Texas Press.

Gregory, Derek and J ohn Urry (eds) (1985) Social Relations and Spatial Structures, London: Macmillan.

Guidry, J ohn (2003) Trial by Space: The Spatial Politics of Citizenship and Social Movements in Urban Brazil', Mobilization, 8(2): 189-204.

Gulick, John (1998) 'The “Disappearance of Public Space”: An Ecological Marxist and Lefebvrian Approach', pp. 135-55 in A. Light and J. Smith (eds) Philosophy and Geography II: The Production of Public Space. Lanham: Rowman and Littlefield.

Harvey, David (1973) Social Justice and the City. Baltimore: Johns Hopkins University Press.

Harvey, David (1982) The Limits to Capital. Oxford: Basil Blackwell.

Harvey, David (1989) The Condition of Postmodernity: An Enquiry into the Origins of Cultural Change, Oxford: Blackwell.

Holder, Jane and Carolyn Harrison (eds) Law and Geography. Oxford: Oxford University Press.

Hyde, Alan (1997) Bodies of Law, Princeton: Princeton University Press.

Isin, Engin (2000) Democracy, Citizenship and the City', pp. 1-21 in E. Isin (ed) Democracy, Citizenship and the Global City. London: Routledge.

Jameson, Fredric (1991) Postmodernism, or, The Cultural Logic of Late Capitalism. Durham: Duke University Press.

Keith, Michael and Steve Pile (eds) (1993) Place and the Politics of Identity. London: Routledge.

Kelly, Michael (1982) Modern French Marxism. Oxford: Basil Blackwell.

Killian, Ted (1998) 'Public and Private, Power and Space', pp. 115-34 in A. Light and J. Smith (eds) Philosophy and Geography II: The Production of Public Space. Lanham: Rowman and Littlefield.

Kofman, Eleonore and Elizabeth Lebas (1996) 'Lost in Transposition: Time, Space and the City', pp. 3-60 in H. Lefebvre (1996) Writings on Cities, Oxford: Blackwell. 
Lefebvre, Henri (1955) 'La Notion de Totalite dans les Sciences Sociales', Cahiers Internationaux de Sociologie, 18: 55-77.

Lefebvre, Henri (1968) Dialectical Materialism. London: Cape.

Lefebvre, Henri (1971) Le Manifeste Differentialiste. Paris: Gallimard.

Lefebvre, Henri (1976) The Survival of Capitalism: Reproduction of the Relations of Production. London: Allison and Busby.

Lefebvre, Henri (1978a) De l'Etat: Les Contradictions de l'Etat Moderne, La Dialectique de l'Etat, Vol IV. Paris: Union Generale d'Editions.

Lefebvre, Henri (1978b) 'Reflections on the Politics of Space', pp. 339-52 in R. Peet (ed) Radical Geography: Alternative Viewpoints on Contemporary Social Issues, London: Methuen.

Lefebvre, Henri (1979) 'Space: Social Product and Use Value', pp. 285-95 in J. Freiberg (ed) Critical Sociology: European Perspectives, New York: Irvington Publishers.

Lefebvre, Henri (1991a) Critique of Everyday Life Vol I: Introduction, London: Verso.

Lefebvre, Henri (1991b) The Production of Space. Oxford: Blackwell.

Lefebvre, Henri (1995) Introduction to Modernity. London: Verso.

Lefebvre, Henri (1996) Writings on Cities, E. Kofman and E. Lebas (eds). Oxford: Blackwell.

Lefebvre, Henri (2002) Critique of Everyday Life Vol II: Foundations for a Sociology of the Everyday. London: Verso.

Lefebvre, Henri (2003a) Key Writings, S. Elden, E. Kofman and E. Lebas (eds). London: Continuum.

Lefebvre, Henri (2003b) The Urban Revolution. Minneapolis: University of Minnesota Press.

Lefebvre, Henri (2004) Rhythmanalysis: Space, Time and Everyday Life. London: Continuum.

Lefebvre, Henri (2005) Critique of Everyday Life Vol III: From Modernity to Modernism (Towards a Metaphilosophy of Daily Life). London: Verso.

Leibniz, Gottfried (1956/1969) Philosophical Papers and Letters, $2^{\text {nd }}$ ed, (Trans. L. Loemker). Boston: D. Reidel Publishing Company.

Manderson, Desmond (1996) 'Beyond the Provincial: Space, Aesthetics, and Modernist Legal Theory', Melbourne Law Review, 20: 1048-71.

Manderson, Desmond (ed) (2005) 'Legal Spaces', Law Text Culture, 9: 1 - 249. 
Martins, M. R. (1982) 'The Theory of Social Space in the Work of Henri Lefebvre', pp. 160-185 in R. Forrest, J. Henderson and P. Williams (eds), Urban Political Economy and Social Theory, Aldershot: Gower.

Marx, Karl (1973) Grundrisse: Foundations of the Critique of Political Economy (Rough Draft), London: Penguin.

Massey, Doreen (1994) Space, Place and Gender. Cambridge: Polity Press.

McCann, Eugene (1999) Race, Protest, and Public Space: Contextualizing Lefebvre in the US City', Antipode, 31(2): 163-184.

McCann, Eugene (2002) 'Space, Citizenship, and the Right to the City: A Brief Overview', GeoJ ournal, 58(2-3): 77-79.

Merrifield, Andy (1995) Lefebvre, Anti-Logos and Nietzsche: An Alternative Reading of The Production of Space', Antipode, 27: 294-303.

Miéville, China (2005) Between Equal Rights: A Marxist Theory of International Law. Leiden: Brill.

Mitchell, Don (1997) The Annihilation of Space by Law: The Roots and Implications of Anti-Homeless Laws', Antipode 29: 303-335.

Mitchell, Don (2003) The Right to the City: Social J ustice and the Fight for Public Space. New York: Guilford Press.

Molotch, Harvey (1993) 'The Space of Lefebvre', Theory and Society, 22: 887-895.

Moran, Leslie and Derek McGhee (1998) 'Perverting London: The Cartographic Practices of Law', Law and Critique, 9(2): 207-24.

Negri, Antonio (2005) Postmodern Global Governance and the Critical Legal Project', Law and Critique, 16(1): 27-46.

Philippopoulos-Mihalopoulos, Andreas (ed) (2007) Law and the City, Abingdon: Routledge-Cavendish.

Poster, Mark (1975) Existential Marxism in Postwar France: From Sartre to Althusser, Princeton: Princeton University Press.

Pue, Wesley (1990) Wrestling With Law: (Geographical) Specificity vs (Legal) Abstraction', Urban Geography, 11(6): 566-85

Purcell, Mark (2002) 'Excavating Lefebvre: The Right to the City and its Urban Politics of the Inhabitant', GeoJ ournal 58: 99-108

Purcell, Mark (2003) 'Citizenship and the Right to the Global City: Reimagining the Capitalist World Order', International J ournal of Urban and Regional Research, 27(3): 564-90

Santos, Boaventura de Sousa (1977) The Law of the Oppressed: The Construction and Reproduction of Legality in Pasargada', Law and Society Review, 12: 5-126. 
Santos, Boaventura de Sousa (1985) 'On Modes of Production of Law and Social Power', International J ournal of the Sociology of Law, 13: 299-336.

Santos, Boaventura de Sousa (1987) 'Law: A Map of Misreading. Toward a Postmodern Conception of Law', Law and Society J ournal, 14(3): 279-302

Santos, Boaventura de Sousa (1992) 'Law, State and Urban Struggles in Recife, Brazil', Social and Legal Studies, 1: 235-55.

Santos, Boaventura de Sousa (1995) Toward a New Common Sense: Law, Science and Politics in the Paradigmatic Transition. London: Routledge.

Sarat, Austin and Thomas Kearns (eds) (1993) Law in Everyday Life. Ann Arbor: University of Michigan Press.

Sayer, Andrew (1993) 'Review: Henri Lefebvre's The Production of Space', International J ournal of Urban and Regional Research, 17(3): 458-9.

Shields, Rob (1999) Lefebvre, Love and Struggle: Spatial Dialectics. London: Routledge.

Soja, Edward (1989) Postmodern Geographies: The Reassertion of Space in Critical Social Theory. London: Verso.

Soja, Edward (2000) Postmetropolis: Critical Studies of Cities and Regions. Oxford: Blackwell.

Stanford Law Review (1996) 'Symposium: Surveying Law and Borders', 48(5): 1037 1430.

Stanley, Christopher (1996) Urban Excess and the Law: Capital, Culture and Desire. London: Cavendish Publishing.

Stewart, Ann and Roger Burridge (1989) 'Housing Tales of Law and Space', J ournal of Law and Society, 16(1): 65-82.

Stewart, Lynn (1995) Bodies, Visions, and Spatial Politics: A Review Essay on Henri Lefebvre's The Production of Space', Environment and Planning D: Society and Space, 13: 609-618.

Tickell, Adam and J amie Peck (1995) 'Social Regulation After Fordism: Regulation Theory, Neoliberalism and the Global-Local Nexus', Economy and Society, 24(3): 357-386.

Unwin, Tim (2000) 'A Waste of Space? Towards a Critique of the Social Production of Space ...', Transactions of the Institute of British Geographers, 25: 11-29.

Valverde, Mariana (2005) Taking 'Land Use' Seriously: Toward an Ontology of Municipal Law', Law Text Culture, 9: 34-59

Watson, Sophie and Katherine Gibson (eds) (1995) Postmodern Cities and Spaces, Cambridge, Mass: Blackwell. 